\title{
The Influence of Delivery and Employee Professionalism on Equity Satisfaction in Batak Indigenous People in Medan City
}

\author{
$1^{\text {st }}$ Farhaya Berlian Noviafni ${ }^{1}, 2^{\text {nd }}$ Dasman Lanin $^{2}, 3^{\text {rd }}$ Boni Saputra $^{3}$

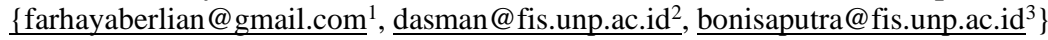 \\ ${ }^{123}$ Magister of Public Administration, Universitas Negeri Padang, Padang, Indonesia
}

\begin{abstract}
The purpose of this study was to analyze the effect of delivery and employee professionalism on equity satisfaction in the indigenous Batak community in Medan. To conduct the study quantitative research approach have been employed. The population in this study is the Batak ethnic community. Sampling technique was used the Slovin formula with a $5 \%$ of error rate, which has produced 200 samples of the community. Determination of the sample used were the Accidental Sampling technique. Data were collected using questionnaires that had distributed to respondents with measurements using a Likert scale. The analysis of the data is based on simple regression analysis and multiple regression. The Findings are discussed in terms of three themes: 1) the delivery variable had an effect on equity satisfaction, 2) the professionalism variable had an effect on equity satisfaction, 3) the delivery variable and professionalism simultaneously had an effect on equity satisfaction.
\end{abstract}

Keywords: Delivery, Professionalism, Equity Satisfaction, Ethnic Batak

\section{Introduction}

The important thing that becomes the priority of every public institution is the provision of services that can increase community satisfaction. This includes many things, from the delivery of services to the results received by the community. Employee professionalism is an important factor that determines community satisfaction, not only in the form of competence and good technical expertise but also an attitude oriented towards providing good service which will have a positive influence on the trust and satisfaction of service recipients. [1] The level of community satisfaction will have a positive impact on the image of the organization, both public and private organizations. Community assessment of the organization can be a reference in improving and enhancing the quality of service, in this case what is meant is an increase in the professionalism of employees' work and the way of delivering the service itself. [2]

The delivery or delivry of service goods or services in the common sector rather than providers to citizens in the local kingdom is a very important determining factor in assessing the relationship and its influence. [3] have found a significant positive relationship between delivery and citizen satisfaction with satisfaction with service in the UK, with the largest contribution compared to other factors at $30 \%$. The attributes he tested in this factor were (1) 
the final outcome of service, (2) how to keep promises (the way the service kept its promises) and (3) how to handle cases (the way service handled any problems). [4] Support the influence of this factor, especially regarding the way services are performed, if it is done by means of coercion, there is no other choice, then citizen satisfaction shows a decrease. However, if the service is indeed the choice of the citizens themselves then they will be satisfied. So citizen satisfaction is based on the method, whether they consume this service forcibly or because of their free choice. Then, how to consume it directly (direct) will satisfy, and in an indirect way (indirect) will not satisfy the citizens. [1]

Investigation [5] also found that the characteristic of thoroughness, which is the same as the final result that can be enjoyed by residents in the attributes of Thomson and Mori, was proven to be a factor that confirmed a significant positive relationship in the delivery of citizens' satisfaction, Froehle's contribution was found to be as much as $35.9 \%$, whether it is mediated by the communication media permissible or not. According to Reveiw [6], one of the main dimensions of citizen service (civic service) lies in whether it provides useful contributions for the local community. The commitment of the providers (providers) to the people served (significant commitment beyond one's self) is one of the key dimensions of satisfying lay services. It should be noted that these significant conveying factors are all perceptions of citizens. Finally, the investigators believe that this factor also proves to be a determinant in the context of this investigation, although [3] they are still concerned about the stability of the effect of this factor, if tested in other countries, so they recommend that it be replicated in various countries before being used as the basis for conducting lay services in the UK.

Professional consists of three elements, namely knowledge, skills, integrity, and then these three elements must be based on unwavering faith, being grateful, and willingness to learn continuously. In addition to the term professionalism, there is a term namely profession. with our daily "job" or "job". But in the word profession does not only contain the meaning of "work." Profession requires not only special knowledge and skills through preparation and training, but in the sense of "profession" there is also a "vocation" That way, the meaning of "profession" contains two elements. First, the element of expertise and the second element of vocation. So that a "professional" must integrate within himself the technical skills needed to carry out his job, as well as ethical maturity. Mastery of technique alone does not make a person to be "professional" because the two of them must blend. [2]

Having a professional spirit, whatever we do will make clients feel satisfied, someone who has a high spirit of professionalism will have the expertise or expertise in optimizing knowledge, skills, time, energy, resources and an achievement strategy that can satisfy all parts / elements. Professional people usually do work autonomously and they devote themselves to service users with a sense of responsibility for their professional abilities. Therefore, it is very important to have a sense of professionalism in every employee, because if you have a professional spirit, whatever you do will satisfy every customer. [3]

Customer needs and wants are number one and if the customer is satisfied, that is the true success of the company. There are many companies that are only concerned with company profits but not necessarily thinking about whether customers are satisfied with the company's services. So having a professional spirit is very important and must be applied by every employee.

Satisfaction is a person's level of satisfaction after comparing the performance or perceived results compared to expectations. So satisfaction or dissatisfaction is a conclusion from the characteristics between expectations and experiences after using the services or services provided. Efforts to achieve total customer satisfaction are not easy things, that total customer satisfaction is not possible, even if only for a short period of time. In principle, service quality 
is focused on activities and efforts to meet the needs and desires of customers as well as the accuracy of its services to balance customer expectations. In other words, there is a major factor affecting the quality of services, i.e. services that are expected and services are perceived. In a study conducted research and [5], that he had concluded there were at least five indicators of service quality (SERVQUAL); first, tangibles, physical evidence of the ability of a company to demonstrate its existence to external parties. Appearance and capabilities of the company's physical infrastructure and the state of the surrounding environment is tangible evidence of the services provided by the service provider. Second, reliability; reliability of the ability of the organization to provide services as promised are accurate and reliable. Performance must be in accordance with customer expectations, mean timeliness, the same service to all customers without error, sympathetic attitude, and with high accuracy. Third, responsiveness, responsiveness is an ability to assist and provide fast service (responsiveness) and the right to the customer with clear information. Forth, assurance; guarantees and assurances that knowledge, politeness, and the ability of an organization's employees to gain confidence of the customers to the company consists of several components; communications, credibility, safety (security), competent, and politeness (courtesy). Fifth, Empathy; which provides a genuine concern and a private individual or given to customers by striving to understand the desires of consumers. [5]

Following [7] in order to create satisfaction there is a teaching known as the theory of equity (Equity theory) which is also called by [8] with equal and fair. Equity theory assumes that citizens will assess the ratio of the results (outcomes) they get and the input they provide in comparison with the results and input of other citizens in an exchange / business management services. If they see that the outcome ratio is higher then as a result they feel unfair. The law of the theory of justice assumes that each party related to the exchange or trade affairs must be treated fairly or properly in the sense that the results (outcomes) obtained and the input of each citizen in the business of service must be the same. If they are not the same, then injustice will act and may cause feelings of dissatisfaction. Conversely, if there is a similarity between them, they will feel that justice is brought about and this will indirectly lead to satisfaction. So citizens are measured by their perceptions of justice rather than service. Inputs include information, effort, money or time required for the transaction, while the results are the benefits of goods or services from services in the form of product performance (performance) and feelings generated from the transaction [9]

[8] in his investigations it has been proven that when the purpose of service is only for a few people (the purpose of only a few individuals), is done with favoritism (favoritism) and services are carried out with consideration or influenced by political pressure, then citizen satisfaction decreases markedly. . In contrast to when bureaucrats act fairly [7] have honest, sincere and impartial ethics and have warm and fair relationships, all of these behaviors have been shown to have a significant positive relationship with increased citizen satisfaction in the service of a layman [8]

Equity satisfaction or equity theory assumes that customers will assess the ratio of the results (results) they get and the input (input) they provide, compared to the results and input of other citizens in a service transaction [2]. The main components of the theory of justice are input, results, justice and injustice. The employee input ratio will compare the results with the results of other input ratios. The indicators used to assess equity satisfaction are: 1) services provided; 2) compliance with expectations; and 3) justice. This satisfaction can be determined by looking at the disconfirmation model, namely if reality / performance $(\mathrm{K})<$ Expectations $(\mathrm{H})$, then apply negative disconfirmation or dissatisfaction, if $K>H$, then apply positive disconfirmation or satisfied and if $\mathrm{K}=\mathrm{H}$, then it is neutral. Indicators used for variables lead to 
more disconfirmation of satisfaction satisfaction consisting of expectations and performance. [10]

[11]stated that the better the governance and quality of service given, the higher the public trust (high trust). Public trust is higher for society to get good service and feel satisfied with the service. Customer satisfaction can be measured using a variety of measurement methods.[12], simply suggests four methods that can measure customer satisfaction, namely as follows:_a. Complaints and Suggestions System, Customer satisfaction survey, Ghost Shopping, Lost Customer Analysis. [13] states that equity theory is a theory of justice that can help explain the relationship between customer perception of the distribution of partner resources, when customers 20 obtain adequate input in service development and when customers are satisfied with the contribution of the mutual service. Customer commitment inappropriate is a consequence of impropriety or injustice in resource distribution. So that customers feel that they are should receive good and undifferentiated service. The results are many disloyal customers. The theory that connects the concept of job satisfaction, turnover and fairness an organization that is well known according to [14] is the Theory of Justice (Equity Theory). This theory suggests that someone will feel satisfied and not satisfied, depending on whether or not equity (Equity) in a situations especially work situations.

Based on the description of the explanation above, the researcher is interested in conducting research with the title the effect of delivery and employee professionalism on equity satisfaction in the indigenous Batak community in Medan.

\section{Methodology}

The method that I use in this research is the quantitative paradigm approach.. there were 200 respondents or samples in this study. Determination of the sample used were the Accidental Sampling technique.the authors intend to collect data and observe carefully certain aspects related to the problem being researched by the researcher so that they will obtain data that can support the preparation of research reports. The variable $(\mathrm{Y})$ of this research is the satisfaction of the Batak ethnic community, while the variable (X1) is Delivery and (X2) is professionalism. The data sources used are primary data and secondary data. In this case the primary data is in the form of the results of filling out the questionnaire by the Medan city tourism office staff. Meanwhile, secondary data is data collected by researchers through books and literature as well as other journals. The study population was the staff of the Medan city tourism office. Samples were collected through accidental sampling technique using the Slovin formula with an error rate of 0.05 . Data collection methods were obtained by using a questionnaire that was distributed directly to respondents. The analysis technique uses a Likert scale. Data were analyzed using SPSS version 25 with simple and multiple analysis. The regression equation in the study is:

$$
\alpha+\beta \mathrm{iX} 1+\beta \mathrm{iX} 2=\mathrm{Y}
$$

Explanation :

$\alpha=$ Constant

$\mathrm{Bi}=$ Delivery regression coefficient

$\mathrm{X} 1=$ Satisfaction of community equity

$\mathrm{X} 2=$ Professionalism 


\section{Finding and Discussion}

\section{Research result}

Based on the data obtained from the questionnaire processed by the researcher, the profile data of the research respondents are as follows:

Table 1. Research Demographic Characteristics

\begin{tabular}{|c|c|c|}
\hline Karakteristik Responden & Jumlah & Persentase \\
\hline $\begin{array}{c}\text { Jenis Kelamin } \\
\text { Laki-laki } \\
\text { Perempuan } \\
\text { Jumlah }\end{array}$ & $\begin{array}{c}87 \\
113 \\
\mathbf{2 0 0} \\
\end{array}$ & $\begin{array}{l}43,5 \% \\
56,5 \% \\
\mathbf{1 0 0} \%\end{array}$ \\
\hline $\begin{array}{l}\text { Etnik } \\
\text { Etnik Aceh Singkil } \\
\text { Jumlah }\end{array}$ & $\begin{array}{l}200 \\
\mathbf{2 0 0}\end{array}$ & $\begin{array}{l}100 \% \\
100 \%\end{array}$ \\
\hline $\begin{array}{l}\text { Usia } \\
<20 \text { tahun } \\
\text { 21-30 tahun } \\
\text { 31-40 tahun } \\
\text { 41-50 tahun } \\
>50 \text { tahun } \\
\text { Jumlah }\end{array}$ & $\begin{array}{c}12 \\
125 \\
43 \\
18 \\
2 \\
\mathbf{2 0 0}\end{array}$ & $\begin{array}{c}6,0 \% \\
62,5 \% \\
21,5 \% \\
9,0 \% \\
1,0 \% \\
\mathbf{1 0 0 \%}\end{array}$ \\
\hline $\begin{array}{l}\text { Pendidikan } \\
\text { SD/Sederajat } \\
\text { SLTP/Sederajat } \\
\text { SLTA/Sederajat } \\
\text { DII/DII/DII } \\
\text { S1 } \\
\text { S2 Jumlah }\end{array}$ & $\begin{array}{l}21 \\
53 \\
81 \\
12 \\
31 \\
2 \\
\mathbf{2 0 0}\end{array}$ & $\begin{array}{c}10,5 \% \\
26,5 \% \\
40,5 \% \\
6,0 \% \\
15,5 \% \\
1,0 \% \\
100 \%\end{array}$ \\
\hline $\begin{array}{l}\text { Pengeluaran } \\
<1.000 .000 \\
1.000 .001-2.500 .000 \\
2.500 .001-4.000 .000 \\
4.000 .001-5.500 .000 \\
>5.500 .000 \\
\text { Jumlah }\end{array}$ & $\begin{array}{c}91 \\
65 \\
27 \\
7 \\
10 \\
\mathbf{2 0 0}\end{array}$ & $\begin{array}{c}45,5 \% \\
32,5 \% \\
13,5 \% \\
3,5 \% \\
5,0 \% \\
\mathbf{1 0 0 \%}\end{array}$ \\
\hline
\end{tabular}

Source: 2020 research questionnaire data

Based on the table above, it can be seen that the dominant respondents are female as many as 113 people with a percentage of $56.5 \%$. All 200 respondents are Batak ethnic community with a dominant age range between $21-30$ as many as 125 people with a percentage of $62.5 \%$. The dominant education level of respondents is high school / equivalent as many as 81 people with a percentage of $40.5 \%$ and finally, the total monthly expenditure of respondents is less than $1,000,000$ as many as 91 people with a percentage of $45.5 \%$. 


\section{a. The influence of Delivery and Professionalism on the satisfaction of public equity}

Following are the results of data processing with the dependent variable, namely the satisfaction of public equity and the independent variable namely Delivery and employee professionalism. The data that has been obtained in the field through a questionnaire are then processed by a simple and multiple regression analysis mechanism, then the results obtained are as follows:

Table 2. The influence of Delivery and Professionalism on the satisfaction of public equity

\begin{tabular}{|c|c|c|c|c|c|}
\hline \multicolumn{6}{|c|}{ Model Summary $^{\text {b }}$} \\
\hline $\begin{array}{c}\text { Mode } \\
1\end{array}$ & $\mathrm{R}$ & R Square & $\begin{array}{l}\text { Adjusted R } \\
\text { Square }\end{array}$ & $\begin{array}{l}\text { Std. Error of } \\
\text { the Estimate }\end{array}$ & $\begin{array}{l}\text { Durbin- } \\
\text { Watson }\end{array}$ \\
\hline 1 & $.566^{\mathrm{a}}$ & .320 & .313 & 2.644 & 1.731 \\
\hline \multicolumn{6}{|c|}{ a. Predictors: (Constant), X2, X1 } \\
\hline
\end{tabular}

From table 2 above, it can be seen that the $\mathrm{R}$ value is 0.566 , the Rsquare value is 0.320 and the Adjusted R Square value is 0.313 , thus the Delivery and Professionalism variables have an influence of $32 \%$ on the equity satisfaction of the Batak ethnic community in Medan.

Table 3. Anova

\begin{tabular}{|c|c|c|c|c|c|c|}
\hline \multicolumn{7}{|c|}{ ANOVA $^{a}$} \\
\hline \multirow{2}{*}{\multicolumn{2}{|c|}{ Model }} & Sum of & Df & Mean Square & $\mathrm{F}$ & Sig. \\
\hline & & Squares & & & & \\
\hline \multirow[t]{4}{*}{1} & Regression & 647.844 & 2 & 323.922 & 46.33 & $.000^{\mathrm{b}}$ \\
\hline & & & & & 1 & \\
\hline & Residual & 1377.311 & 197 & 6.991 & & \\
\hline & Total & 2025.155 & 199 & & & \\
\hline \multicolumn{7}{|c|}{ a. Dependent Variable: Y } \\
\hline \multicolumn{7}{|c|}{ b. Predictors: (Constant), X2, X1 } \\
\hline
\end{tabular}

From the table above, it can be seen that the calculated $F$ value is 46,331 with a significance level of $0.0(0.00<0.05)$, which means that the regression model can be used to predict participatory variables or in other words there is the influence of the Delivery (X1) and Professionalism (X2) variables. ) on the satisfaction variable of public equity (Y). 
Table 4. Coefficient

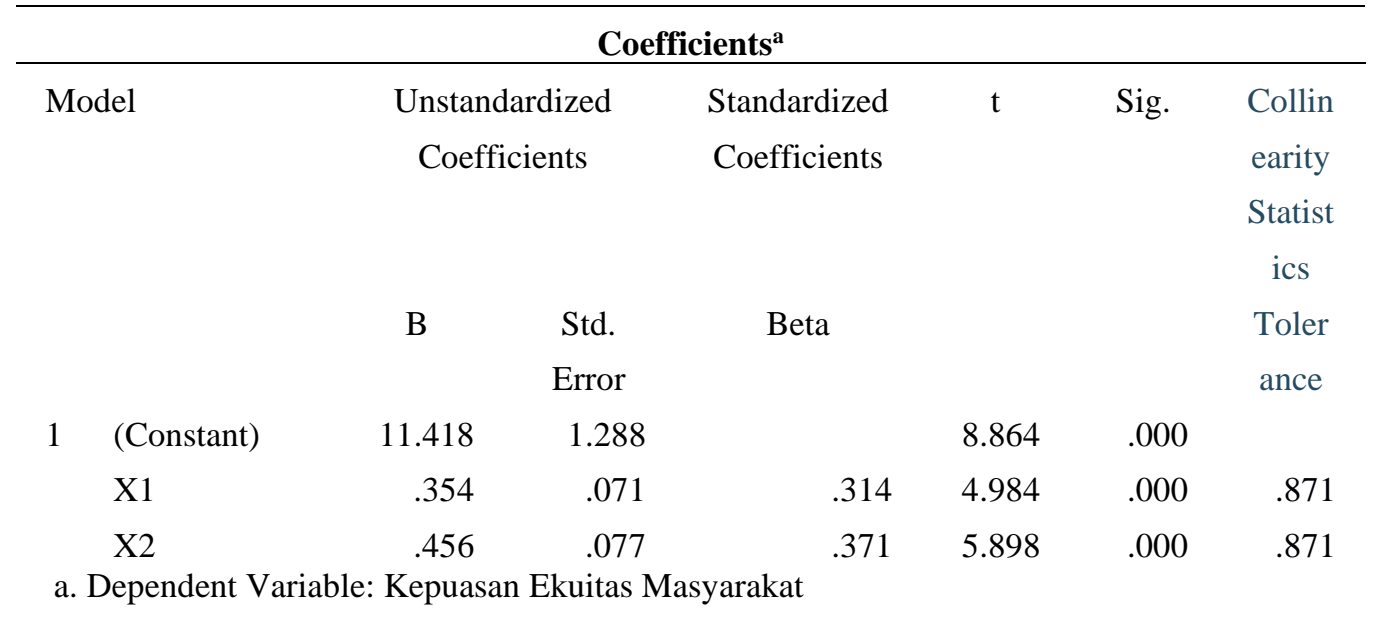

Based on the table above, it is known that the value of Constant (a) is 11.418, while the value of Delivery (X1) (b / regression coefficient) is 0.354 and the value of professionalism is 0.456 . So that the regression equation can be written as follows:

$$
\begin{gathered}
a+b X_{1}+X_{2}=Y \\
11,418+0,354 X 1+0,456 X 2=Y
\end{gathered}
$$

This equation can be translated into the consistent value of the public equity satisfaction variable is 11.418 . The regression coefficient $\mathrm{X} 1$ is 0.354 and the $\mathrm{X} 2$ coefficient is 0.456 which states that every $1 \%$ addition of the internal political value of the organization increases the participation value by 0.111 . This regression coefficient is positive, so it can be said that the direction of the influence of the variable $\mathrm{X}$ on $\mathrm{Y}$ is positive. The significance value obtained is $0.00(0.005<0.05)$, which means that the Delivery and Professionalism variables have an effect on the satisfaction of community equity in Batak in Medan City. If seen from the value of $t$ count 4.984 and 5.898> 1.970 ( $\mathrm{t}_{\text {table }}$ ), this means that variable $\mathrm{X}$ affects variable $\mathrm{Y}$ because $\mathrm{t}$ is greater than table

\section{Discussion}

The Delivery variable (X1) and the professionalism variable (X2) in this study had a $32 \%$ level of influence on the equity satisfaction of the Batak ethnic community in Medan City with a significance level of 0.00 . This means that the results of this study are at a $100 \%$ level of confidence and have a positive influence. The results of this study support previous research which states that one that affects external customer equity satisfaction is Professionalism and Delivery. 


\section{Conclusion}

From this research, it can be concluded that this research can conclude that delivery and professionalism have an effect on the satisfaction of community equity in the Batak ethnic group in Medan City with an influence of $32 \%$ with a significant 0.00 and the effect is positive. Based on the research that the author has done, it can be suggested to the government of Medan City, especially the Medan City Tourism Office, to improve the quality of delivery or delivery and also the professionalism of its employees in providing services to the community. So that public satisfaction with the services provided by the government increases and gets better.

\section{References}

[1] R. Agusti and P. P. Nastia, "Pengaruh Kompetensi, Independensi Dan Profesionalisme Terhadap Kualitas Audit (Studi Empiris Pada Kantor Akuntan Publik Se Sumatera)," J Chem Inf Model, vol. 53, no. 9, pp. 168-99, 2013.

[2] E. R. Iftikar, M. Suyudi, and Rafiqoh., "Pengaruh Profesionalisme, Komitmen Organisasi, Intensitas Moral Karyawan Terhadap Whistleblowing (Studi Kasus Pada PT Cipta Krida Bahari Samarinda),” J. Akunmulti Dimens., vol. 1, no. 1, pp. 10-20, 2018.

[3] W. \& M. Thomson, "Customer Satisfaction With Key Public Services," www.cabinetoffice.gov.uk/opsr., 2014. .

[4] Brown T, Coersion versus choice : citizen evaluations of public service quality across methods of consumption. 2007.

[5] C. M. Froehle, "Service personnel, technology and their interaction in influencing cutomer satisfaction,” J. Compil., vol. Volume 37, 2006.

[6] J. L. Perry, Service With A Smile. Oxford: University Press, 2006.

[7] J. O'Kelly, C\& Dubnick, M, Taking Tough Choices Seriously: Public Administration and Individua Moral Agency, vol. 16. Oxford: University Press, 2009.

[8] E. Vigado-Gadot, "Citizen's Perceptions of Politics and Ethics in Public Administration: A Five-Year National Study of Their Relationship to Satisfaction with Services, Trustin Governance, and Voice Orientations," in JPART, vol. 17, Oxford, 2008.

[9] S. D. M. And and S. Heni, "Restructuring the Corruption Law Enforcement Model that Optimizes Corporation as Corruption Subject of Criminal Act," 2018.

[10] S. Astuti, Wenny, Lanin, Dasman, "The Effect of Employee Satisfaction on Service Quality Through Delevery and Profesisionalsm in Labor and Industrial Agency of Padang City," in Advances in Social Science, Education and Humanities Research, 2019, vol. 458 .

[11] harbani pasolog, Teori Administrasi Publik, Alfabeta. 2010.

[12] F. Tjiptono, Total Quality Service. 2003.

[13] D. dan U. S.-G. Roeffen, "The Importance of Customer Co-Creation of Value for the Tourism and Hospitality Industry. Open Tourism, Tourism on the Verge.," Univ. Innsbruck, Austria, 2016.

[14] V. Rivai, Manajemen Sumber Daya Manusia Untuk Perusahaan. 2004. 